\title{
TRENDS IN SMOKING AMONG SECONDARY SCHOOL AND HIGH SCHOOL STUDENTS IN POLAND, 2009 AND 2011
}

PAULINA WOJTYŁA-BUCIORA ${ }^{1,2}$, BARBARA STAWIŃSKA-WITOSZYŃSKA ${ }^{3}$, WIOLA ŻUKIEWICZ-SOBCZAK ${ }^{4}$, CEZARY WOJTYŁA ${ }^{5}$, PIOTR BILIŃSKI ${ }^{6}$, MONIKA URBANIAK ${ }^{7}$, ANDRZEJ WOJTYŁA ${ }^{2}$, JERZY T. MARCINKOWSKI ${ }^{8}$, and MAŁGORZATA WOJCIECHOWSKA ${ }^{9}$

${ }^{1}$ Poznan University of Medical Sciences, Poznań, Poland

Department of Physiology

${ }^{2}$ State Higher Vocational School in Kalisz, Kalisz, Poland

Faculty of Medicine

${ }^{3}$ Poznan University of Medical Sciences, Poznań, Poland

Chair of Social Medicine, Department of Epidemiology

${ }^{4}$ Pope John Paul II State School of Higher Education in Biała Podlaska, Biała Podlaska, Poland

Department of Public Health

${ }^{5}$ Centre of Postgraduate Medical Education, Warszawa, Poland

I Department of Obstetrics and Gynecology

${ }^{6}$ Institute of Psychiatry and Neurology in Warsaw, Warszawa, Poland

III Psychiatric Clinic

${ }^{7}$ Poznan University of Medical Sciences, Poznań, Poland

Chair and Department of Facility Management Organizations in Health Care

${ }^{8}$ Poznan University of Medical Sciences, Poznań, Poland

Chair of Social Medicine, Department of Hygiene

${ }^{9}$ Poznan University of Medical Sciences, Poznań, Poland

Department of Mother and Child Health

Funding: the study was supported by a nationwide project "Health behaviors of middle school and high school students" funded and carried out by the Sanitary Inspection in Poland. Project manager: Assoc. Prof. Andrzej Wojtyła.

Received: July 15, 2015. Accepted: August 11, 2016.

Corresponding author: P. Wojtyła-Buciora, Poznan University of Medical Sciences, Department of Physiology, Święcickiego 6, 61-781 Poznań, Poland (e-mail: paulinawojtyla@gmail.com). 


\begin{abstract}
Objectives: To determine the age and the most common circumstances for smoking initiation along with smoking rates and to evaluate smoking trends for secondary and high school students in Poland during 2009 and 2011. Material and Methods: In 2009, a pilot study was conducted in districts of Poland on high school students and their parents. For statistical analysis, correctly completed questionnaires from 999 students and 667 parents were qualified for use. After the pilot study, a nationwide study of secondary school students and their parents was also conducted in 2009. For statistical analysis, correctly completed questionnaires were used from 9360 students and 6951 from their parents. The research tool was a questionnaire developed by the Chief Sanitary Inspectorate. These studies were then compared to the nationwide research study from 2011. Questionnaires were obtained from a survey of 3548 students from secondary schools and 4423 of those from high schools. Results: Smoking initiation usually begins at ages 12-15 years. Rates of secondary school student smoking at least once in their lifetime were about the same level in the surveyed years $(2009-9 \%, 2011-11 \%)$, whereas rates of high school student smoking increased $(2009-15 \%, 2011-24 \%)$. Moreover, 34\% of secondary school student smoked less than once a week, whereas in 2009, only $8 \%$ of students had done so. For high school students, a 1/2 smoked every day; similar to 2009. Students usually smoked in parks, on streets or any other open space areas. Conclusions: From analyzing the smoking trends over the survey period it can be concluded that the problem of smoking increases with respondent age. Int J Occup Med Environ Health 2017;30(5):763-773
\end{abstract}

Key words:

Health education, Cigarette smoking, High school students, Tobacco epidemiology, Smoking initation, Secondary school students

\section{INTRODUCTION}

Tobacco smoking constitutes one of the most important health threats and causes of premature mortality. Not only is it a medical problem but also a social, ethical and economic issue. Epidemiological data suggest that global smoking prevalence affects more than a billion people, of which $1 / 4$ are adults. Each year smoking kills about 5.2 million people worldwide which is higher than the combined mortalities from tuberculosis, human immunodeficiency virus infection/acquired immune deficiency syndrome (HIV/ AIDS) and malaria. It is estimated that this number may increase up to 8 million in 2030 [1]. In Poland, smoking affects 9 million people of whom nearly 5 million have been smoking for longer than 20 years. Smoking has been tried by $90 \%$ of adolescents aged $<18$ years, whilst $60 \%$ have done so $<14$ years of age [2].

Upon starting smoking their first cigarette, youngsters report dizziness or headache, nausea, vomiting and impaired cardiac function. Smoking becomes a habit when a body's natural sensitivity is overcome by toxic effects; primarily of nicotine. In tobacco, nicotine is a powerful addictive drug, most widely used around the world in the form of cigarettes, cigars, chewing tobacco, pipe tobacco and snuff. Dependence rates vary according to many factors, but are principally due to the effects that nicotine and other smoke components have on the human body. After reaching the brain, nicotine binds to nicotinic receptors through which specific receptors become activated by releasing dopamine, a neurotransmitter linked to addiction. Teenage brains are especially susceptible to addiction and lose control over their smoking habits within a few weeks after their first cigarette [3]. Each day, 100000 young people become addicted to nicotine [1].

For a long time, adverse symptoms of chronic poisoning in heavy smokers had not been apparent. Scientific research focused especially on cardiology and oncology has demonstrated a strong connection between smoking and disease incidence of the cardiovascular system and cancer [4-7].

The World Health Organization (WHO), in collaboration with governmental and nongovernmental organizations, have taken many steps for countering the tobacco epidemic. A key role is played by the accurate monitoring of people's use of tobacco products; both nationally and internationally.

\section{Study aims}

1. Determining the age and the most common circumstances at which nicotine initiation begins in secondary school and high school students in Poland. 
2. Estimating smoking rates and numbers of cigarettes smoked by secondary school and high school students.

3. Evaluating smoking trends in secondary school and high school students during 2009 and 2011.

4. Assessing smoking prevalence for parents of secondary school and high school students in Poland in 2009.

\section{MATERIAL AND METHODS}

In 2009, a pilot study had been conducted on high school students and their parents in a district of Poland. Subjects were a random sampling of 1100 high school students, together with the same number of their parents. Questionnaires were completed by 999 students and 667 parents which qualified for statistical analysis. The study group consisted of 679 girls and 320 boys.

The research tool was a questionnaire developed by the Chief Sanitary Inspectorate (Główny Inspektorat Sanitarny), based on the questionnaire used in the Global School-Base Student Health Survey. Questionnaires were sent not only to the students, but also to their parents to obtain more reliable data on selected unhealthy and healthy behaviours of the subjects.

After the pilot studies from the same year, a nationwide study of secondary school students and their parents was carried out. In the Polish educational system, the 'gimnazjum' (secondary school) is an educational level providing secondary education for students aged 13-16 years. Graduation from this level allows students to attend high school, either 'liceum' (high school) or 'technikum' (technical college), where the latter are for students aged 16-19 years. The national 2009 survey sampled 12005 students and the same number of parents where 9360 students and 6951 parents correctly completed questionnaires from which the data were used for statistical analysis. The study group consisted of 4961 girls and 4399 boys.

For diagnosing the smoking problems in different age groups, these studies were compared with the national
2011 survey. In that survey, a random-selected group of adolescents from secondary and high schools were asked to fill in questionnaires.

The sample comprised 10083 students, of whom 7971 (79\%) correctly completed questionnaires that could be used for statistical analysis; of these 3548 were students from secondary schools and 4423 from high schools. In the former there were 1742 girls and 1806 boys and in the latter 2275 girls and 2148 boys. In 2011, students' parents were not interviewed, as 2009 studies demonstrated a poor agreement between child-parent responses.

The questionnaire had been expanded to include questions about a new health-related problem faced by adolescents: intake of so-called designer drugs, i.e., novel psychoactive substances. It was found that responses on smoking prevalence were more detailed than previously. In the 2009-2011 surveys, representative samples of secondary and high school students were selected in 2 stages; first, a school was chosen, and then a class.

Only those class students who completed the anonymous questionnaire were recruited. The sample consisted of 569 schools from 379 counties and the size of sample was estimated by assuming that there are 25 students per class. In fact, classes had fewer students, hence in 2009 the sample size was set at 12005 students of secondary schools, whilst in 2011 at 10083 students from secondary and high schools. The student sample was selected from the database of schools at the Ministry of National Education from 30 September 2008. Selected schools were grouped taking into account a number of factors: country population and type (urban or village), province (16 different provinces), school type (secondary school, high school, technical college) and class (age of students selected in the classes). The classes were drawn with the aid of system procedures Statistica 12.

Students completed an anonymous questionnaire, and the data obtained from it were loaded into a central database. Statistical analysis used the Statistica 12 for 
Windows package. The $\mathrm{Chi}^{2}$ test of independence was used for nominal variables, each with $\geq 2$ possible values. A $p \leq 0.05$ was considered significant.

\section{RESULTS}

The results of nationwide research conducted in 2009 and 2011 among secondary school and high school students show that teenagers usually start smoking at the age of $12-15$ years, that is in secondary school $(\mathrm{p}<0.001)$ (Table 1). When analyzing association and also accounting for gender, both secondary and high school female students commence smoking at the age of 12-15 whereas the boys have their first cigarette at 8-11 years.

The questionnaire data show that the proportion of students who smoked at least once in their life has remained at a similar level. In 2009, $9 \%$ of secondary school students had smoked at any time in life, and in 2011 this increased to $11 \%$. Our findings show that smoking among adolescents increases with age. Significantly more high school students smoked throughout the period of the questionnaire: in 2009, the proportion was $15 \%$, and it significantly increased to $24 \%$ in 2011 ( $p=0.002)$ (Figure 1).

The analysis of 2009 data showed that, in both age groups of smokers, 50\% subjects reported smoking cigarettes

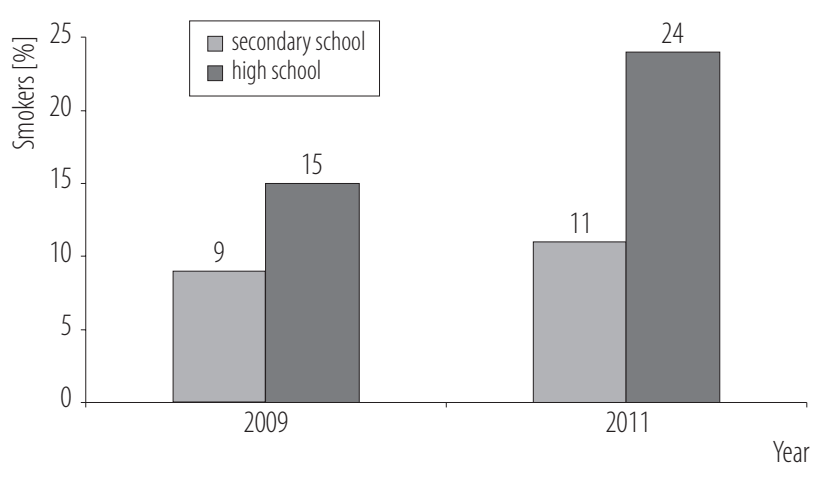

Fig. 1. Secondary and high schools students smoking cigarettes (once or more in a lifetime) in 2009 and 2011 in Poland

every day and nearly $25 \%$ smoked a few times a week. Questions included in the 2011 survey were more detailed and contained more response options so that smoking prevalence could be more accurately estimated. Questions were on the number of cigarettes smoked within the last 30 days. Over the last month, $30 \%$ of secondary school students smoked a cigarette daily. Just as in 2009, nearly $1 / 2$ of the high school students smoked daily. When comparing 2009 with 2011, proportions of daily smokers were lower in 2011 for secondary school students. Moreover, $34 \%$ of secondary school students smoked less than once a week, whereas in 2009 only $8 \%$ of students did so. Similarly to 2009, 1/2 of the high school students smoked daily $(\mathrm{p}=0.003)($ Table 2$)$.

Table 1. Smoking initiation of secondary and high schools students in Poland in 2009 and 2011 - by gender

\begin{tabular}{|c|c|c|c|c|c|c|c|c|}
\hline \multirow{4}{*}{$\begin{array}{c}\text { Smoking } \\
\text { initiation age } \\
\text { [years] }\end{array}$} & \multicolumn{8}{|c|}{$\begin{array}{c}\text { Respondents } \\
(\mathrm{N}=2419) \\
{[\mathrm{n}(\%)]}\end{array}$} \\
\hline & \multicolumn{4}{|c|}{2009} & \multicolumn{4}{|c|}{2011} \\
\hline & \multicolumn{2}{|c|}{ secondary school } & \multicolumn{2}{|c|}{ high school } & \multicolumn{2}{|c|}{ secondary school } & \multicolumn{2}{|c|}{ high school } \\
\hline & $\begin{array}{c}\text { girls } \\
(\mathrm{N}=393)\end{array}$ & $\begin{array}{c}\text { boys } \\
(\mathrm{N}=449)\end{array}$ & $\begin{array}{c}\text { girls } \\
(\mathrm{N}=69)\end{array}$ & $\begin{array}{c}\text { boys } \\
(\mathrm{N}=71)\end{array}$ & $\begin{array}{c}\text { girls } \\
(\mathrm{N}=165)\end{array}$ & $\begin{array}{c}\text { boys } \\
(\mathrm{N}=213)\end{array}$ & $\begin{array}{c}\text { girls } \\
(\mathrm{N}=506)\end{array}$ & $\begin{array}{c}\text { boys } \\
(\mathrm{N}=553)\end{array}$ \\
\hline$<7$ & $12(3)$ & $40(9)$ & $2(3)$ & $5(7)$ & $5(3)$ & $28(13)$ & $20(4)$ & $55(10)$ \\
\hline 8-11 & $110(28)$ & $171(38)$ & $8(12)$ & $15(21)$ & $42(26)$ & $66(31)$ & $71(14)$ & $116(21)$ \\
\hline $12-15$ & $271(69)$ & $238(53)$ & $42(61)$ & $39(55)$ & $115(71)$ & $117(56)$ & $324(64)$ & $299(54)$ \\
\hline $16-18$ & $0(0)$ & $0(0)$ & $17(24)$ & $12(17)$ & $0(0)$ & $0(0)$ & $91(18)$ & $83(15)$ \\
\hline
\end{tabular}


Table 2. The prevalence of cigarette smoking by students of secondary and high schools in Poland in 2009 and in the last month before the questioning in 2011

\begin{tabular}{|c|c|c|c|c|}
\hline \multirow{3}{*}{$\begin{array}{l}\text { Cigarettes smoking } \\
\text { frequency }\end{array}$} & \multicolumn{4}{|c|}{$\begin{array}{c}\text { Respondents } \\
(\mathrm{N}=2419) \\
{[\mathrm{n}(\%)]}\end{array}$} \\
\hline & \multicolumn{2}{|c|}{2009} & \multicolumn{2}{|c|}{2011} \\
\hline & $\begin{array}{l}\text { secondary school } \\
(\mathrm{N}=842)\end{array}$ & $\begin{array}{l}\text { high school } \\
(\mathrm{N}=140)\end{array}$ & $\begin{array}{l}\text { secondary school } \\
(\mathrm{N}=378)\end{array}$ & $\begin{array}{l}\text { high school } \\
(\mathrm{N}=1059)\end{array}$ \\
\hline Daily & $421(50)$ & $70(50)$ & $113(30)$ & $519(49)$ \\
\hline Several times a week & $202(24)$ & $35(25)$ & $80(21)$ & $233(22)$ \\
\hline Once a week & $152(18)$ & $14(10)$ & $57(15)$ & $148(14)$ \\
\hline Less than once a week & $67(8)$ & $21(15)$ & $128(34)$ & $159(15)$ \\
\hline
\end{tabular}

Compared to 2009, the number of cigarettes smoked by adolescents decreased in 2011. Despite an increased number of adolescents who smoked at least once in their lives, the number of students smoking daily decreased. Subjects from both age groups usually smoked 3-5 cigarettes daily, and smoking rates of 6-10 cigarettes/day or $>10$ cigarettes/day were lower $(\mathrm{p}<0.001)$ (Table 3). Moreover, within the last 12 months, $59 \%$ of secondary school students and $55 \%$ of high school students, respectively, intended to give up smoking.

Statistical 2011 data showed that secondary school and high school students usually smoke in parks, on streets or any other open space area. Among other places preferred were discos, school areas and the family home ( $p<0.001)$ (Figure 2). It is, however, of concern that $83 \%$ of secondary school students and $88 \%$ of high school students smoke in the company of friends. Undoubtedly peer pressure bears a significant effect on whether to smoke among adolescents. It was indeed confirmed that $44 \%$ of respondents had obtained a cigarette from their peers $(\mathrm{p}<0.001)$ (Figure 3$)$.

The 2009 study was directed not only at children but also their parents. Two separate questionnaires checked the compliance in replies from children and their parents. For the secondary school and high school students reviewed in 2009, there was no child/parent agreement.

Table 3. Cigarettes smoked per day by secondary and high schools students in Poland in 2009 and in the last month before the questioning in 2011

\begin{tabular}{|c|c|c|c|c|}
\hline \multirow{3}{*}{$\begin{array}{c}\text { Cigarettes smoked } \\
{[\mathrm{n} / \mathrm{day}]}\end{array}$} & \multicolumn{4}{|c|}{$\begin{array}{c}\text { Respondents } \\
(\mathrm{N}=2419) \\
{[\mathrm{n}(\%)]}\end{array}$} \\
\hline & \multicolumn{2}{|c|}{2009} & \multicolumn{2}{|c|}{2011} \\
\hline & $\begin{array}{l}\text { secondary school } \\
\quad(\mathrm{N}=842)\end{array}$ & $\begin{array}{l}\text { high school } \\
(\mathrm{N}=140)\end{array}$ & $\begin{array}{l}\text { secondary school } \\
\quad(\mathrm{N}=378)\end{array}$ & $\begin{array}{l}\text { high school } \\
(\mathrm{N}=1059)\end{array}$ \\
\hline$>10$ & $185(22)$ & $39(28)$ & $38(10)$ & $148(14)$ \\
\hline $6-10$ & $185(22)$ & $39(28)$ & $60(16)$ & $286(27)$ \\
\hline $3-5$ & $219(26)$ & $39(28)$ & $155(41)$ & $445(42)$ \\
\hline $1-2$ & $253(30)$ & $23(16)$ & $0(0)$ & $0(0)$ \\
\hline$<1$ & $0(0)$ & $0(0)$ & $125(33)$ & $180(17)$ \\
\hline
\end{tabular}




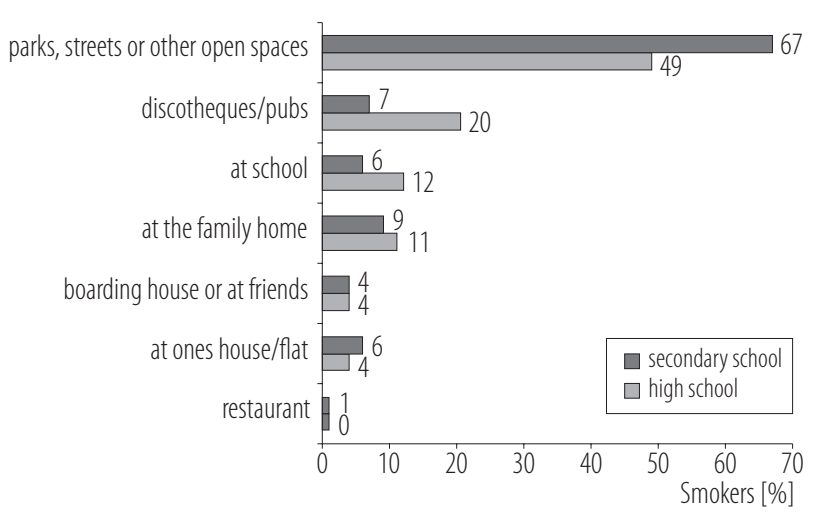

Fig. 2. Usual smoking places of secondary and high school students as indicated by respondents of the 2011 (Poland) survey

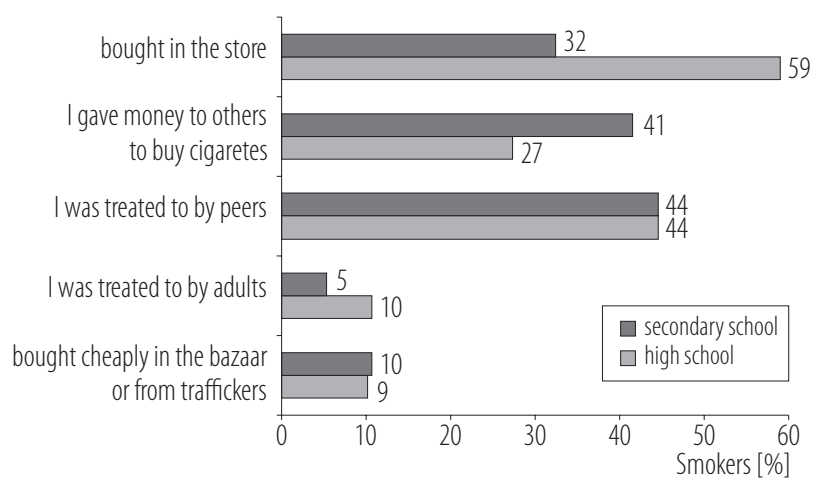

Fig. 3. The circumstances of acquiring of cigarettes by secondary and high schools students in 2011 in Poland

According to parents, only $2 \%$ of students smoked at least once in their lives whereas, according to students, the corresponding values were $9 \%$ and $15 \%$ for secondary school and high school students, respectively. Due to this poor agreement, students' parents were not surveyed in 2011. In 2011, the following questions: "Which of your household members smokes?” and „Do this/these person(s) smoke in your presence?" were answered by the students in 2011. According to adolescents, $15 \%$ of secondary school students' parents and $16 \%$ of high school students' parents smoked. According to the adolescent subjects, their parents frequently smoked in the presence of household members: $24 \%$ of secondary school students' parents and $36 \%$ of high school students' parents did so.

\section{DISCUSSION}

The age at which children experiment with cigarettes is decreasing and the fact that some will become regular smokers is one of the most important problems regarding tobacco smoking in Poland [8]. The survey shows that smoking initiation usually occurs at $12-15$ years of age. The main causes of early nicotine initiation are curiosity, the need for peer acceptance and willingness to make impression. The study also found that $62 \%$ of secondary school students and 59\% of high school students start smoking during their school time. Whenever they change their place of education, there is a need to fit in to a new environment, and therefore behaviour also changes. The mechanism of adolescent smoking is associated with the need to demonstrate maturity which is exacerbated especially in people with a lowered self-esteem and those being mentally or socially immature.

The prevalence of smoking increases with age. The study showed that in 2011, $11 \%$ of secondary school students and more than twice as much $(24 \%)$ high school students smoked at least once in their lives. The proportion of adolescent smokers significantly increased. In 2009, $15 \%$ of high school students smoked cigarettes, but already in 2011 this number increased by $9 \%$. Other Polish studies confirm these findings; around $26 \%$ of high school students from cities and 31\% from rural areas are smokers [9].

It should be noted that the proportion of adolescents who smoked at least once in their lives can be underestimated as it is illegal in Poland to sell cigarettes to persons aged $<18$ years. Furthermore, despite the assurance of responder anonymity, it is likely that, because of legal concerns, students might have refused to confess that they had started smoking.

A further study on teenage smoking is planned for 2016. The aim will be to use a common questionnaire for all age groups. In this study, the questionnaire used in 2011 differs from the one in 2009. Adding more detailed questions has made the study results more difficult to compare. 
Trends for tobacco use in the United States were monitored by the National Youth Tobacco Survey carried out at secondary and high schools in 2009 and 2011. That research showed that in 2011, more than $7 \%$ of secondary school students and $23 \%$ of high school students were current smokers [10]. Literature reports show that most smokers beginning to smoke before 18 years of age, often fall into making this a habit [11].

The latest data show that young men aged 20-34 years declare they began daily smoking at 18.2 years, whilst girls of the same age group began smoking almost 2 years later (i.e., 20.1 years on average) [12]. The alarming fact is that in most European Union countries teenage girls smoke cigarettes at the same rates as boys and sometimes even more frequently [13]. Research on Health Behaviour in School-Aged Children in Poland has shown a drastic increase in the proportion of smoker girls during 1990-1998 [12]. At this time, proportion of smokers among 13-year-old girls increased from $3 \%$ to $10 \%$ and for 15 -year-olds from $16 \%$ to $28 \%$. Another study from 2002 and 2006 demonstrated that this growing trend in smoking halted and then reversed, especially for girls aged 15 to $20 \%$ [14]. Our results confirm this dependence, which shows that $9 \%$ of secondary-school girls and $22 \%$ of high-school girls had smoked cigarettes at least once in their lifetime. A reason for early initiation of tobacco use is the common notion that this will allow them to maintain a slim figure or help in losing weight. Indeed, American research has proved that the habit of smoking cigarettes in girls is perceived as a tool to control body weight [15].

The most important characteristics of smoking habit are the frequency and number of cigarettes smoked per day. Our 2011 study showed that a 1/3 of secondary school students and $1 / 2$ of the high school students reported smoking daily. It is not exceptional for teenagers to smoke up to 20 cigarettes daily [16]. The Global Youth Tobacco Survey (GYTS) demonstrated that in the 15-19 years group, the average number of cigarettes smoked per day was 14 [17]. In our 2009 study, 22\% of secondary school students and $28 \%$ of high school students smoked $>10$ cigarettes daily. Despite the increased number of adolescent smokers, the number of cigarettes smoked per day has reduced almost by half. If this is related with increasing tobacco product prices, it proves to be a particularly important method for preventing smoking among young people. In regard to the above discussion one wonders why young people so easily develop the smoking habit? Siqueira et al. [18] showed that cigarette smoking by students coincides with non-adaptive methods of coping with stress. This points to the need for introducing psychological counselling to schools. Such a psychological clinic was created for students and staff at the Medical University in Poznań, Poland. Unable to cope with stress, adolescents smoke cigarettes and often in the face of emerging problems, react with a sense of helplessness, hopelessness or guilt. Focusing on incurred failures, adolescents avoid social contacts and trigger aggression against themselves or others. Therefore, according to researchers, any preventive measures should not only rely on information on the dangers of nicotine, but should also be focused on creating programs for helping young people to recognise the symptoms of stress and teach them to use positive and adaptive stress coping techniques.

This relationship is also confirmed by our study, which shows that young people often combine tobacco and alcohol, or they intensify the desired effect of drinking alcohol by additionally taking drugs and boosters $[19,20]$.

Undoubtedly, peer pressure significantly impacts on smoking. Our 2011 survey showed that in both groups, $44 \%$ of adolescents get cigarettes from their friends and $>80 \%$ students smoke in the company of their peers. Adolescent smoking is a group phenomenon. The functioning of such groups is undoubtedly linked to a disrupted educational process by their parents resulting from the lack of supervision or approval. This relationship 
is confirmed by our study, which shows that $10 \%$ of young people smoke cigarettes in the family home. Moreover, the 2009 study shows that parents are unaware of their children's smoking initiation or that they marginalize it.

Forming healthy attitudes in adolescents is also affected by parental smoking in the presence of children. This coaddiction in family circles makes it difficult for deciding to break the habit. Persons living in a smoking environment inhale smoke exhaled by a smoker into the ambient air together with the smouldering smoke and are thus exposed to passive (or forced involuntary) smoking [21]. Passive exposure is widespread and affects a large part of the population at home and in the workplace. The Global Tobacco Surveillance System launched during 1999-2006 in 132 countries shows that $44 \%$ of children up to 15 years and $42 \%$ of young people aged 16-19 years are exposed to the harmful effects of tobacco smoke in their home [22]. The Global Youth Tobacco Survey studies have shown that exposure to environmental tobacco smoke can be up to $90 \%[17,23]$.

Our study showed decrease in the prevalence of smoking by parents. However, those with the smoking habit frequently smoke in the presence of family members consisting of $24 \%$ secondary school students' parents and $36 \%$ of high school students' parents. In recent years, numerous studies on the adverse health effects of tobacco smoke exposure in children and adolescents have been performed [24]. It is estimated that in the United States, passive smoking is an annual cause of 200000 early childhood asthma cases [25]. It also increases the risk of coronary heart disease to 25-30\% and lung cancer to 20-30\% [4]. Because of the magnitude of this problem, all the ways of combating tobacco consumption, especially by educational campaigning targeted at children and adolescents, are vital. No less important is to conduct an appropriate campaign for raising the awareness of the smoker parents on the adverse effects of smoking on themselves and their children. Costs incurred for such campaigns would certainly be balanced out quickly, as reducing the amount of cigarettes smoked should result in reduced treatment costs of tobacco-related diseases, higher workday productivity and fewer disability pensions, thus reducing the burden on the state budget. Anti-smoking education should be conducted primarily by physicians, schoolteachers and beyond, sociologists, psychologists, the clergy, the media - often and in various forms. All possible propaganda tools of promoting the value of life without a cigarette should be used, e.g., presenting celebrities from politics, science, art, who are nonsmokers and who speak out against smoking - all can become positive role models. In Poland, at the turn of the century the "Quit and Win" campaign of Countrywide Integrated Noncommunicable Diseases Intervention (CINDI) via a WHO coordinated programme, alongside the national campaign "Stop smoking with us" proved to be the most effective method for addressing tobacco control [26].

The programs have contributed to public health education, propagated innovative methods to reduce smoking in public health leaders and encouraging them towards further educational and interventional activity.

Most studies base their analysis on measures for preventing the initiation of smoking, and only a small amount deal with the problem of smoking cessation [27]. There are also psychological symptoms associated with withdrawal, such as depression, nervous tension, fits of anger, or fatigue [28]. Therefore, overcoming addiction is a very difficult process. Research shows that $25 \%$ of adolescent smokers aged 17-18 years want to give up the habit, but only $5 \%$ succeed [29]. It should be noted that in the 2011 study, 59\% of secondary school students and $55 \%$ of high school students declared an intention to give up smoking.

According to WHO, 3 out of 4 smokers are aware of the dangers of tobacco smoking and tries to give up [28]. However, as in the case of drug addicts, most smokers are unable to overcome their addiction.

There are many aids for helping smoking cessation, but they are not always effective. These include pharmacologic 
agents, nicotine chewing gum, nicotine patches or herbal products. Undoubtedly, in the fight against addiction, the smoker's motivation and strong will is important [1]. It has been noted that for many millions of motivated smokers around the world, as many as $90 \%$ have abandoned the habit without using any other means. Motivation is thereby an important consideration arising from reasons of health, finance, influence of relatives and on legal aspects of prohibition.

\section{CONCLUSIONS}

The nationwide studies performed in 2009 and 2011 demonstrate that teenagers usually start smoking at the ages of 12-15 years, whilst receiving secondary school education. There is, therefore, a need for monitoring this age group in order to initiate actions aimed at health promotion and education.

The survey conducted in 2011 shows that the proportion of secondary school students who smoked at least once in their lives does not significantly differ compared to that noted in 2009.

The number of secondary school students who smoke daily is lower, with also less daily cigarettes being smoked. Smoking becomes more problematic with age. In 2011, the proportions of students who smoked at least once in their lives increased compared to 2009. The number of daily smokers remains the same, however, the number of cigarettes smoked daily decreased.

Peer pressure considerably contributes to smoking initiation as the respondents usually get their first cigarette from their friends.

Secondary school students usually smoke in parks, in the streets or in any other open space areas.

Responses from research in 2009 received from secondary and high school students showed poor agreement between children and their parents on of how much the adolescents smoked. Parents believe that their offspring smoke significantly less than their children report.

\section{ACKNOWLEDGMENTS}

Authors express their gratitude to Mr. Przemysław Biliński, Chief Sanitary Inspector, for allowing us to perform the nationwide survey. We also thank Mr. Jacek Zwoliński for providing help and indications in the translation of the article.

\section{REFERENCES}

1. World Health Organization. WHO report on the global tobacco epidemic, 2013. Enforcing bans on tobacco advertising, promotion and sponsorship. Geneva: The Organization; 2013 [cited 2015 May 20]. Available from: http://www.who.int/tobacco/global_report/2013/en.

2. Jassem J, Przewoźniak K, Zatoński W. Tobacco control in Poland - Successes and challenges. Transl Lung Cancer Res. 2014 Oct;3(5):280-5, https://doi.org/10.3978/j.issn.2218-6751. 2014.09.12.

3. Glover ED, Glover PN, Payne TJ. Treating nicotine dependence. Am J Med Sci. 2003 Oct;326(4):183-6, https://doi. org/10.1097/00000441-200310000-00006.

4. U.S. Department of Health and Human Services. The health consequences of involuntary exposure to tobacco smoke: A report of the Surgeon General. Atlanta: U.S. Department of Health and Human Services, Center for Disease Control and Prevention, Coordinating Center for Health Promotion, National Center for Chronic Disease Prevention and Health Promotion, Office on Smoking and Health; 2006 [cited 2015 May 20]. Available from: http://www.surgeongeneral.gov/library/reports/secondhandsmoke/fullreport.pdf.

5. Yusuf S, Hawken S, Ounpuu S, Dans T, Avezum A, Lanas F, et al. Effect of potentially modifiable risk-factors associated with myocardial infarction in 52 countries (the INTERHEART Study): Case-control study. Lancet. 2004 Sep 11-17;364(9438): 937-52, https://doi.org/10.1016/S0140-6736(04)17018-9.

6. Czyżykowski R, Połowinczak-Przybyłek J, Potemski P. Nicotine-induced resistance of non-small cell lung cancer to treatment - Possible mechanisms. Postepy Hig Med Dosw (Online). 2016 Mar 4;70:186-93, https://doi.org/10.5604/17322 693.1196391. 
7. Yang P, Wang Y, Wampfler JA, Xie D, Stoddard SM, She J, et al. Trends in subpopulations at high risk for lung cancer. J Thorac Oncol. 2016 Feb;11(2):194-202, https://doi.org/ 10.1016/j.jtho.2015.10.016.

8. Rzeźnicki A, Kowalska A, Krakowiak J, Chowański K, Stelmach W. [Frequency of smoking tobacco, drinking alcohol and using drugs by the junior high school youth]. Przegl Lek. 2014;71(11):588-91. Polish.

9. Sygit K, Kołłątaj W, Wojtyła A, Sygit M, Bojar I, Owoc A. Engagement in risky behaviours by 15-19-year-olds from Polish urban and rural areas. Ann Agric Environ Med. 2011;18(2):404-9.

10. Centers for Disease Control and Prevention. Current tobacco use among middle and high school students - United States, 2011. MMWR Morb Mortal Wkly Rep. 2012 Aug 10; 61(31):581-5.

11. Panatto D, Amicizia D, Domnich A, Lai PL, Cristina ML, Signori A, et al. Tobacco smoking among students in an urban area in Northern Italy. J Prev Med Hyg. 2013 Jun;54(2):97-103.

12. Currie C, Roberts C, Morgan A, Smith R, Settertobulte W, Samdal O, et al., editors. Young people's health in context. Health Behaviour in School-aged Children (HBSC) study: International report from the 2001/2002 survey. Health policy for children and adolescents, No. 4 [Internet]. Copenhagen: World Health Organization; 2004 [cited 2015 May 20]. Available from: http://www.euro.who.int/_data/assets/pdf_ file/0008/110231/e82923.pdf.

13. Kaleta D, Usidame B, Biliński P, Raciborski F, Samoliński B, Wojtyła A, et al. Global Adult Tobacco Survey (GATS) in Poland 2009-2010 - Study strengths, limitations and lessons learned. Ann Agric Environ Med. 2012;19(4):717-22.

14. The Health Behaviors in School-age Children (HBSC) 2005/2006 Survey. School report. Bethesda: National Institutes of Health: National Institutes of Child Health and Human Development [cited 2015 May 20]. Available from: https://www.nichd.nih.gov/publications/pubs/documents/ HBSC-2005_2006-Final.pdf.

15. Stice E, Martinez EE. Cigarette smoking prospectively predicts retarded physical growth among female adolescents.
J Adolesc Health. 2005 Nov;37(5):363-70, https://doi.org/10. 1016/j.jadohealth.2004.10.017.

16. Caraballo RS, Novak SP, Asman K. Linking quantity and frequency profiles of cigarette smoking to the presence of nicotine dependence symptoms among adolescent smokers: Findings from the 2004 National Youth Tobacco Survey. Nicotine Tob Res. 2009 Jan;11(1):49-57, https://doi.org/10.1093/ntr/ntn008.

17. Usmanova G, Mokdad AH. Results of the Global Youth Tobacco Survey and implementation of WHO Framework Convention on Tobacco Control in former Soviet Union countries. Int J Public Health. 2013 Apr;58(2):217-26, https://doi.org/10.1007/s00038-012-0433-2.

18. Siqueira LM, Rolnitzky LM, Rickert VI. Smoking cessation in adolescents: The role of nicotine dependence, stress, and coping methods. Arch Pediatr Adolesc Med. 2001 Apr;155(4):489-95, https://doi.org/10.1001/archpedi. 155.4.489.

19. Wojtyła-Buciora P, Wojtyła C, Urbaniak M, Kapka-Skrzypczak L, Wojtyła A, Diatczyk J, et al. Alcohol consumption in Polish middle and high school pupils - Has this rapidly increased during 2009-11? Ann Agric Environ Med. 2014;21(3):552-6, https://doi.org/10.5604/12321966. 1120600.

20. Wojtyła-Buciora P, Wojtyła A, Wojtyła C, Marcinkowski JT. [Prevalence of alcohol consumption according to high school students and their parents]. Hygeia Public Health. 2012;47(4):498-504. Polish.

21. Raisamo SU, Doku DT, Heloma A, Rimpelä AH. Persistence of socioeconomic differences in adolescents' environmental tobacco smoke exposure in Finland: 1991-2009. Scand J Public Health. 2014 Mar;42(2):184-93, https:/doi. org/10.1177/1403494813514301.

22. GTSS Collaborative Group. A cross-country comparison of exposure to second-hand smoke among youth. Tob Control. 2006 Jun;15 Suppl 2:ii4-19.

23. Kaleta D, Polańska K, Wojtysiak P, Kozieł A, Kwaśniewska M, Miśkiewicz P, et al. Effective protection from exposure to environmental tobacco smoke in Poland: The World Health 
Organization perspective. Int J Occup Med Environ Health. 2010;23(2):123-31, https://doi.org/10.2478/v10001-010-0014-7.

24. Warren CW, Jones NR, Eriksen MP, Asma S; Global Tobacco Surveillance System (GTSS) Collaborative Group. Patterns of global tobacco use in young people and implications for future chronic disease burden in adults. Lancet. 2006 Mar;367(9512):749-53, https://doi.org/10.1016/S01406736(06)68192-0.

25. Carlsen KH, Lodrup-Carlsen KC. Parental smoking and childhood asthma: Clinical implications. Treat Respir Med. 2005;4(5):337-46, https://doi.org/10.2165/00151829200504050-00005.

26. Suwała M, Gerstenkorn A, Drygas W. [How to effectively limit tobacco smoking? Experiences of CINDI-WHO pro- gram in Poland]. Hygeia Public Health. 2014;49(1):26-32. Polish.

27. Daniel JZ, Cropley M, Fife-Schaw C. The effect of exercise in reducing desire to smoke and cigarette withdrawal symptoms is not caused by distraction. Addiction. 2006 Aug;101(8): 1187-92, https://doi.org/10.1111/j.1360-0443.2006.01457.x.

28. Boudreaux ED, Francis JL, Carmack Taylor CL, Scarinci IC, Brantley PJ. Changing multiple health behaviors: Smoking and exercise. Prev Med. 2003;36(4):471-8, https://doi.org/ 10.1016/S0091-7435(02)00048-8.

29. Wang LY, Michael SL. Long-term health and medical cost impact of smoking prevention in adolescence. J Adolesc Health. 2015 Feb;56(2):160-6, https://doi.org/10.1016/j.jadohealth.2014.08.025.

This work is available in Open Access model and licensed under a Creative Commons Attribution-NonCommercial 3.0 Poland License - http://creativecommons.org/ licenses/by-nc/3.0/pl/deed.en. 